\title{
Radiolytic Gas Generation in Crystalline Silicotitanate Slurries
}

by

D. D. Walker

Westinghouse Savannah River Company

Savannah River Site

Aiken, South Carolina 29808
RECEIVED

JAN 102000

OSTI

DOE Contract No. DE-AC09-96SR18500

This paper was prepared in connection with work done under the above contract number with the U.S.

Department of Energy. By acceptance of this paper, the publisher and/or recipient acknowledges the U.S. Government's right to retain a nonexclusive, royalty-free license in and to any copyright covering this paper, along with the right to reproduce and to authorize others to reproduce all or part of the copyrighted paper. 


\section{DISCLAIMER}

This report was prepared as an account of work sponsored by an agency of the United States Government. Neither the United States Government nor any agency thereof, nor any of their employees, makes any warranty, express or implied, or assumes any legal liability or responsibility for the accuracy, completeness, or usefulness of any information, apparatus, product or process disclosed, or represents that its use would not infringe privately owned rights. Reference herein to any specific commercial product, process or service by trade name, trademark, manufacturer, or otherwise does not necessarily constitute or imply its endorsement, recommendation, or favoring by the United States Government or any agency thereof. The views and opinions of authors expressed herein do not necessarily state or reflect those of the United States Government or any agency thereof.

This report has been reproduced directly from the best available copy.

Available for sale to the public, in paper, from: U.S. Department of Commerce, National Technical Information Service, 5285 Port Royal Road, Springfield, VA 22161

phone: (800) 553-6847

fax: (703) 605-6900

email: orders@ntis.fedworld.gov

online ordering: http://www.ntis.gov/ordering.htm

Available electronically at http://www.doe.gov/bridge

Available for a processing fee to U.S. Department of Energy and its contractors, in paper, from: U.S. Department of Energy, Office of Scientific and Technical Information, P.O. Box 62, Oak Ridge, TN 37831-0062

phone: (865)576-8401

fax: (865)576-5728

email: reports@adonis.osti.gov 


\section{DISCLAIMER}

Portions of this document may be illegible in electronic image products. Images are produced from the best available original document. 
WSRC-TR-99-00285, Rev. 0

Keywords: Waste processing, ion exchange, hydrogen, oxygen

Retention: Permanent

\section{RADIOLYTIC GAS GENERATION IN CRYSTALLINE SILICOTITANATE SLURRIES}

D. D. Walker

Publication Date: September 17, 1999

Westinghouse Savannah River Company

Savannah River Technology Center

Aiken, SC 29808

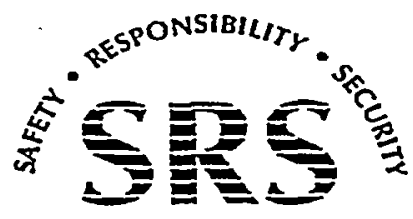

SAVANNAH RIVER SITE 
WSRC-TR-99-00285, Rev. 0

Page 2 of 19

Radiolytic Gas Generation

In Crystalline Silicotitanate Slurries

Author

Darrel O. Libeller

$9117 / 99$

D. D. Walker, Waste Processing Technology

Date

Design Check

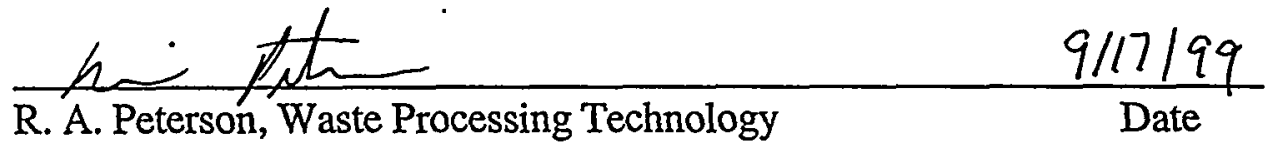
(per Manual E7, Procedure 2.40)

Approvals

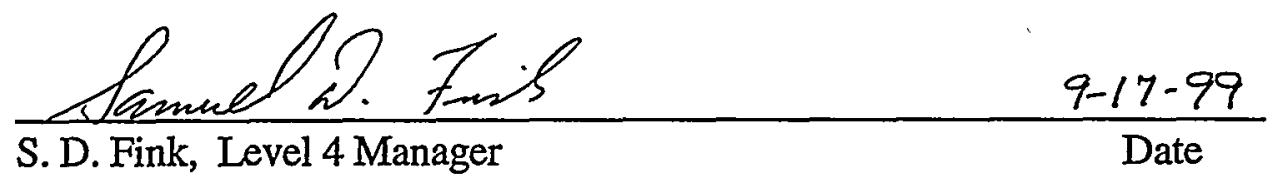

Waste Processing Technology

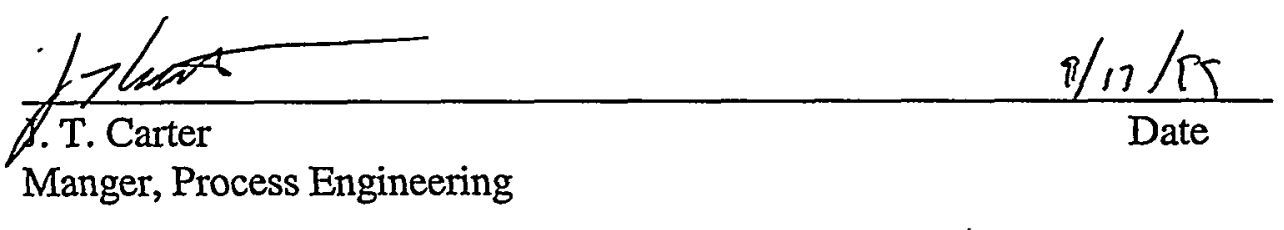

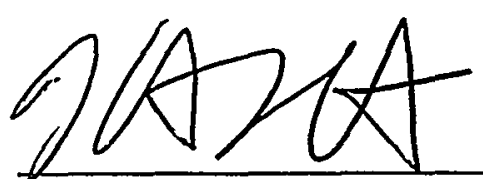

K. J. Rueter $\frac{9 / 17 / 99}{\text { Date }}$

Director, Salt Disposition Alternatives Engineering

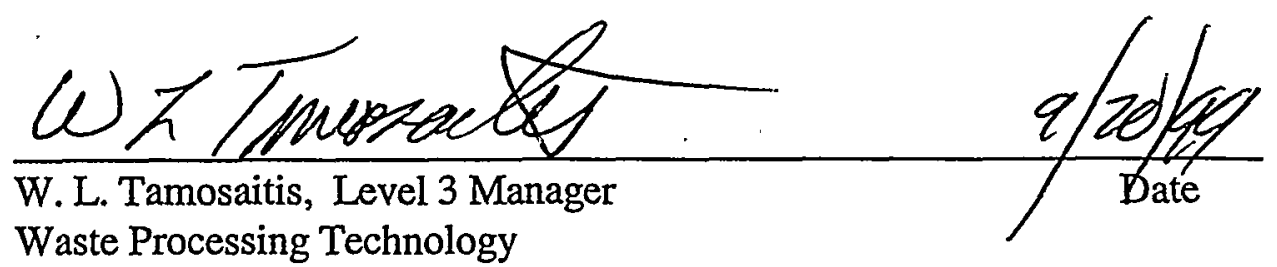

Waste Processing Technology 


\section{CONTENTS}

SUMMARY

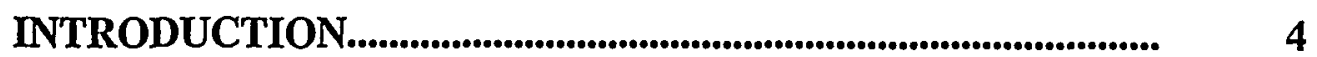

TEST DESCRIPTION AND RESULTS........................... 5

Gas Bubble Formation............................................................... 5

Gas Generation and Composition............................................ 9

SUMMARY ......................................................... 12

ACKNOWLEDGMENTS.......................................... 13

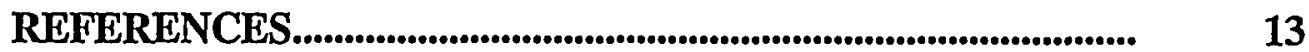

APPENDIX A. Experimental....................................... 15 


\title{
RADIOLYTIC GAS GENERATION IN CRYSTALLINE SILICOTITANATE SLURRIES
}

\author{
By D. D. WALKER
}

\section{SUMMARY}

This study measured the impact of crystalline silicotitanate (CST) solids on the rate of formation and composition of radiolytically generated gases in simulated Savannah River Site liquid waste. The tests used IONSIV TM IE-911 (UOP LLC, Molecular Sieves Division, Des Planes, IL), the engineered form of CST. The test results show the following.

- Radiolytically generated gas bubbles form rapidly at expected process dose rates.

- Bubbles formed within 8 hours at a dose rate of $1 \mathrm{Mrad} / \mathrm{h}$.

- Bubbles can move by displacing IONSIVTM IE-911 particles if close to the surface.

- In a $6 \mathrm{~cm}$ column, the bed expanded $\sim 20 \%$ due to trapped bubbles, before steady state release of bubbles occurred.

- Alkaline waste solutions extracted a component of the IONSIVTM IE-911 and subsequently deposited the component as a finely divided solid.

- Irradiation of IONSIV ${ }^{\mathrm{TM}}$ IE-911 slurries produces hydrogen, oxygen, and nitrous oxide $\left(\mathrm{N}_{2} \mathrm{O}\right)$.

- Oxygen is the major product from irradiation of high nitrate waste; hydrogen is the major product from irradiation of high hydroxide waste.

- IONSIV ${ }^{\mathrm{TM}}$ IE-911 does not effect hydrogen production from high nitrate waste, but doubled hydrogen production from high hydroxide waste.

$-\mathrm{N}_{2} \mathrm{O}$ is a minor product ( $<4 \mathrm{vol} \%$ of gases produced).

- Researchers measured total radiolytic gas generation rates lower than those used in a preliminary gas generation calculation for a full-scale process column. ${ }^{1}$

- High nitrate waste solutions yield the largest gas generation rates.

- The previous calculation ${ }^{1}$ for total gas generation remains bounding because test results showed less oxygen formation ( $G$ values up to 0.15 molecules $/ 100 \mathrm{eV}$ ) than assumed in the calculation $(0.3$ molecules $/ 100 \mathrm{eV})$.

\section{INTRODUCTION}

A non-elutable ion exchange process is one of the alternatives for removing cesium from Savannah River Site (SRS) soluble radioactive waste. ${ }^{2}$ Crystalline silicotitanate particles 
in the engineered form (IONSIVTM IE-911) are the reference ion exchange medium for the process. An IONSIV ${ }^{\mathrm{TM}} \mathrm{EE}-911$ ion exchange column sorbs Cs-137 and, when fully loaded, contains $\sim 500 \mathrm{Ci} / \mathrm{L}$. ${ }^{1}$ The $\mathrm{Cs}-137$ produces a dose rate approaching $1 \mathrm{Mrad} / \mathrm{h}$ which generates hydrogen, oxygen, and possibly other gases from the waste stream. The effect of the gas on column performance is a significant concern for the ion exchange process alternative. This study examined the rate and composition of the gases produced when simulated waste was irradiated in the presence of IONSIVTM $\mathbb{E}-911$. A previous study examined hydrogen gas generation in the presence of IONSIVTM IE-911. ${ }^{3}$ The earliertest results indicated IONSIV ${ }^{\mathrm{TM}} \mathrm{EE}-911$ did not enhance production of hydrogen gas compared to expected gas generation from the liquid phase. Energy deposited in the IONSIV ${ }^{\mathrm{TM}}$ IE-911 did not transfer to the liquid phase in a manner producing hydrogen gas when tested in water, sodium hydroxide, or simulated SRS average waste. The author initiated additional tests to quantify generation rates of gases other than hydrogen and from waste simulants other than the average composition.

This work partially fulfills a request from J. R. Fowler, Technical Task Request, "Ion Exchange Column Tests to Reflect Effects of Radioactive Waste, 9.1 Gas Generation Tests," \#HLW-SDT-TTR-99-09.1, January 21, 1999. The work complies with the following test plan: D. D. Walker, "Task Technical and Quality Assurance Plan for NonElutable Ion Exchange Process Gas Generation Tests," WSRC-RP-99-00189, Rev.0, February 26, 1999.

\section{TEST DESCRIPTION AND RESULTS}

Researchers conducted two types of experiments. In the first, researchers photographically recorded the growth of gas bubbles in irradiated IONSIVTM IE-911 slurries. In the second, researchers measured the formation rate and composition of the gas bubbles. Table I lists the composition of the salt solutions used in the experiments. Appendix A provides further details of the experimental methods.

\section{Gas Bubble Formation}

Researchers placed slurries of IONSIVTM IE-911 in $0.1 \mathrm{M} \mathrm{NaOH}$ solution or in high nitrate simulated waste (composition shown in Table I) into $1.5-\mathrm{cm}$ diameter quartz cylinders and irradiated them at $1.01 \mathrm{Mrad} / \mathrm{h}$ for seven days. Figure 1 shows the growth of gas bubbles. The scale shown behind the cylinders is marked in centimeters and provides an estimate of the volume changes in the slurry.

Researchers observed gas bubbles when examining the cylinders eight hours after starting the irradiation. After 24 hours, discrete gas bubbles from $1 \mathrm{~mm}$ to $1 \mathrm{~cm}$ in diameter appeared in the upper half of the packed bed. In the lower half of the packed bed, the gas displaced the liquid phase without moving the IONSIV ${ }^{\mathrm{TM}}$ IE-911 particles. The different behavior between the upper and lower portions of the bed likely results from pressure differences from the mass of overlying particles. The packed bed of IONSIVTM IE-911. and the total liquid level increased by 15 to $20 \%$ during irradiation, indicating the amount 


\section{TABLE I. Composition of Simulated Waste Solutions}

\begin{tabular}{|c|c|c|}
\hline \multirow[b]{2}{*}{ Component } & \multicolumn{2}{|c|}{ Concentration (molar) } \\
\hline & High OH & High $\mathrm{NO}_{3}^{-}$ \\
\hline$\overline{\mathrm{Na}^{+}}$ & 5.6 & 5.6 \\
\hline $\mathrm{K}^{+}$ & 0.030 & 0.0041 \\
\hline $\mathrm{Cs}^{+}$ & 0.00037 & 0.00014 \\
\hline $\mathrm{OH}^{-}$ & 3.05 & 1.17 \\
\hline $\mathrm{NO}_{3}^{-}$ & 1.10 & 2.84 \\
\hline $\mathrm{NO}_{2}^{-}$ & 0.74 & 0.37 \\
\hline $\mathrm{AlO}_{2}^{-}$ & 0.27 & 0.32 \\
\hline $\mathrm{CO}_{3}^{2-}$ & 0.17 & 0.16 \\
\hline $\mathrm{SO}_{4}{ }^{2-}$ & 0.030 & 0.22 \\
\hline $\mathrm{Cl}^{-}$ & 0.010 & 0.040 \\
\hline $\mathrm{F}$ & 0.010 & 0.050 \\
\hline $\mathrm{PO}_{4}{ }^{3-}$ & 0.008 & 0.010 \\
\hline $\mathrm{C}_{2} \mathrm{O}_{4}^{2-}$ & 0.008 & 0.008 \\
\hline $\mathrm{SiO}_{3}{ }^{2-}$ & 0.004 & 0.004 \\
\hline $\mathrm{MoO}_{4}{ }^{2-}$ & 0.0002 & 0.0002 \\
\hline
\end{tabular}

Density (g/mL) $\quad 1.236 \pm 0.017 \quad 1.250 \pm 0.016$

of gas trapped in the bed. Neither sample increased significantly in volume after the first day, although the $0.1 \mathrm{M} \mathrm{NaOH}$ slurry decreased in volume. The changing shape and distribution of the bubbles on subsequent days indicate that gas formation did not cease, but rather, bubbles of gas escaped the packed bed and rose to the surface. Researchers noted that tapping the sides of the apparatus dislodged additional bubbles.

During the irradiation test, the simulated waste solution above the packed bed became yellowish, cloudy, and deposited a white solid on the walls of the quartz apparatus. The following control tests in the quartz apparatus failed to produce the white solids on the upper walls:

- simulated waste solution held at $37^{\circ} \mathrm{C}$ (no solids present),

- simulated waste solution irradiated at $37^{\circ} \mathrm{C}$ (no solids present), and

- IONSIV ${ }^{\mathrm{TM}}$ IE-911 in simulated waste solution at $37^{\circ} \mathrm{C}$.

Using energy-dispersive $x$-ray spectroscopy (EDXS), researchers determined that the deposits contained primariliy a proprietary component of the IONSIVTM IE-911. Similar solids formed during pretreatment of the IONSIV ${ }^{\mathrm{TM}} \mathrm{IE}-911$ in the radioactive waste column test. ${ }^{4}$ Researchers postulate that the solids form by extraction of the proprietary component under high $\mathrm{pH}$ conditions followed its by precipitation as a different compound. Gas bubbles formed during radiolysis stirred the packed bed and dispersed the precipitated solids in the waste solution above the bed. The third control test failed to produce the solids on the upper surface because of the absence of a transport mechanism. 
FIGURE 1. Gas Bubble Formation During Irradiation
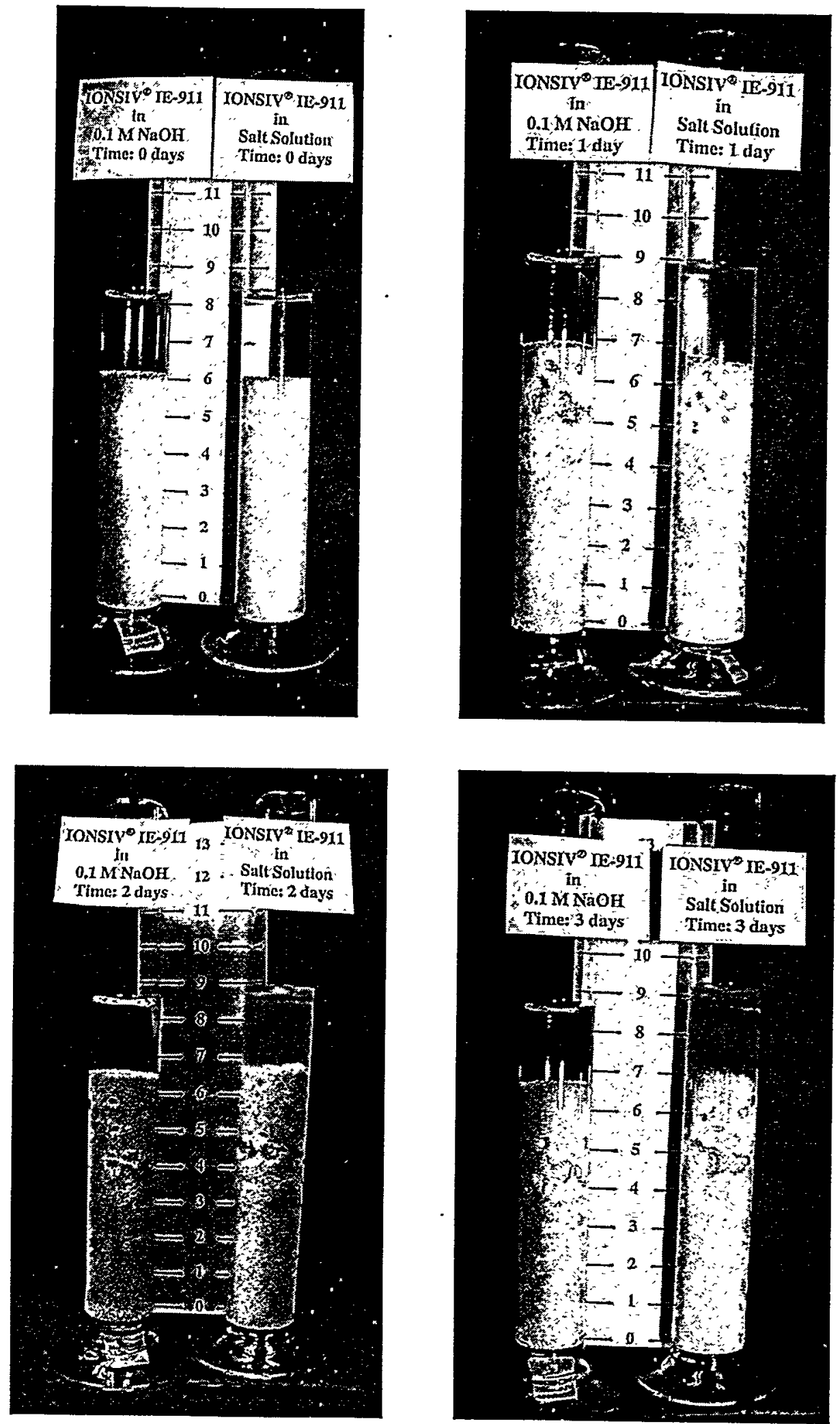
FIGURE 1. Gas Bubble Formation During Irradiation (continued)
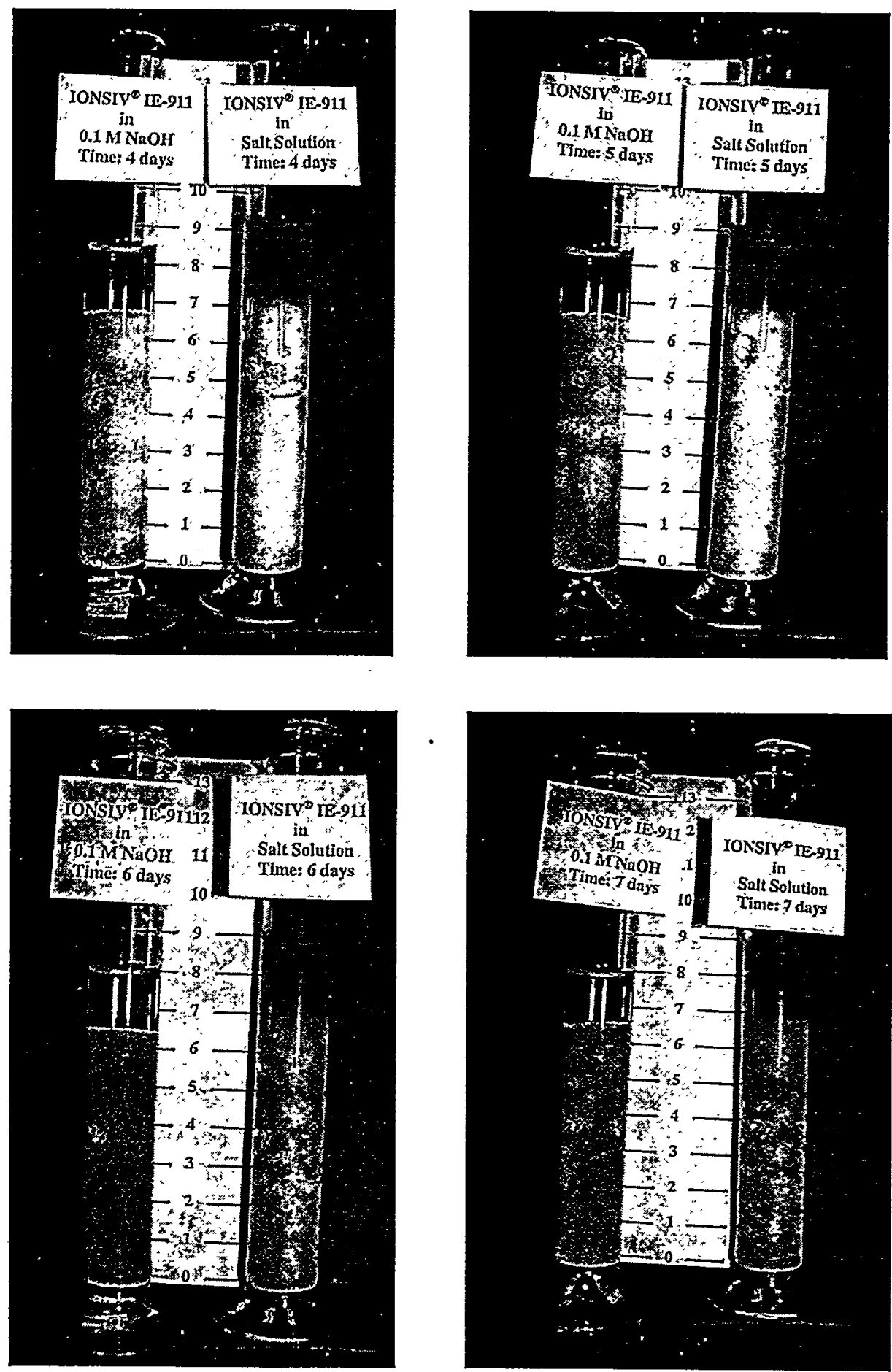


\section{Gas Generation and Composition}

Researchers irradiated a high nitrate simulated waste solution and slurries of IONSIVTM IE-911 in high nitrate or high hydroxide waste solutions (Table I). The irradiation apparatus trapped the radiolytically generated gas. Table II lists the total gas generation rates. Figure 2 shows results of a typical experiment. Corrections applied to the observed volume changes account for loss of liquid sample as gas accumulates. The results of the experiments are expressed as $\mathrm{G}_{\text {tot }}$ values (yield of gas per unit amount of adsorbed energy, or molecules $/ 100 \mathrm{eV}$ ). $G_{\text {tot }}$ values are the sum of $G$ values for individual gases.

The $\mathrm{G}_{\text {tot }}$ value for the high nitrate salt solution exceeds that for the corresponding slurry because the solids in the slurry adsorb a portion of the radiation. The high nitrate slurry produces more gas than the high hydroxide slurry because nitrate ion decreases hydrogen production and increases oxygen production. The effects increase as the nitrate ion concentration increases. The following equations summarize these reactions.

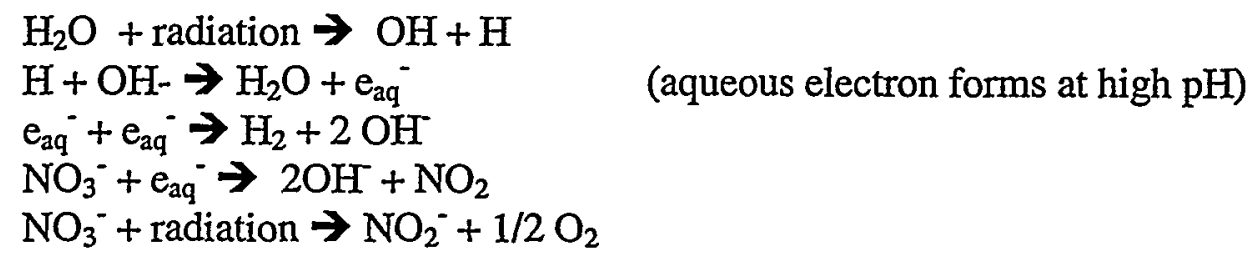

Table III lists the gas compositions. Hydrogen and oxygen were the major gases produced. Small amounts of $\mathrm{N}_{2} \mathrm{O}$ were found. Since $\mathrm{N}_{2} \mathrm{O}$ is slightly soluble in aqueous solutions, the actual yield is likely larger than indicated by the gas analysis. Carbon dioxide was not detected in any of the experiments (detection limit $0.01 \mathrm{vol} \%$ ). This result was expected because the alkaline salt solution adsorbs $\mathrm{CO}_{2}$ to form carbonate ion. Minor amounts of carbon monoxide, methane, and ethane were detected, but these likely originate from irradiation of the septum used to seal the apparatus. However, the amounts appear to vary consistently with the composition of the sample being irradiated, suggesting a connection.

The high nitrate solution and slurry produce predominantly oxygen gas (Table III). The presence of IONSIV ${ }^{T M}$ IE-911 appears to have minor effects: the hydrogen yield increases by $10 \%$, the oxygen yield decreases by $5 \%$, and the $\mathrm{N}_{2} \mathrm{O}$ yield becomes $2.3 \%$. These calculations assume a portion of the oxygen (proportional to the nitrogen), the methane, ethane, and carbon monoxide are sampling impurities. Although consistent, the differences in produced gases between solution and slurry are small and approach the analytical error. The high hydroxide slurry produces predominantly hydrogen gas. With the high nitrate solution or slurry, the sum of the gases measured was near $100 \%$. In the high hydroxide slurry, the sum of the gases is $\sim 90 \%$, suggesting production of an unidentified gas or a bias in the measurement of large amounts of hydrogen. 
TABLE II. Total Gas Generation Rates*

Sample

High nitrate solution

High nitrate IONSIV'M IE-911 slurry

High OH/IONSIV ${ }^{\mathrm{TM}}$ IE-911 slurry

$$
\mathbf{G}_{\text {tot }} \text { Value }
$$

(molecules $/ 100 \mathrm{eV})$

$0.170,0.163$

$0.105,0.110,0.111$

$0.076,0.071$

*Based on total dose (i.e., energy adsorbed by solid and liquid phases).

FIGURE 2. Accumulation of Gas in Irradiation Apparatus

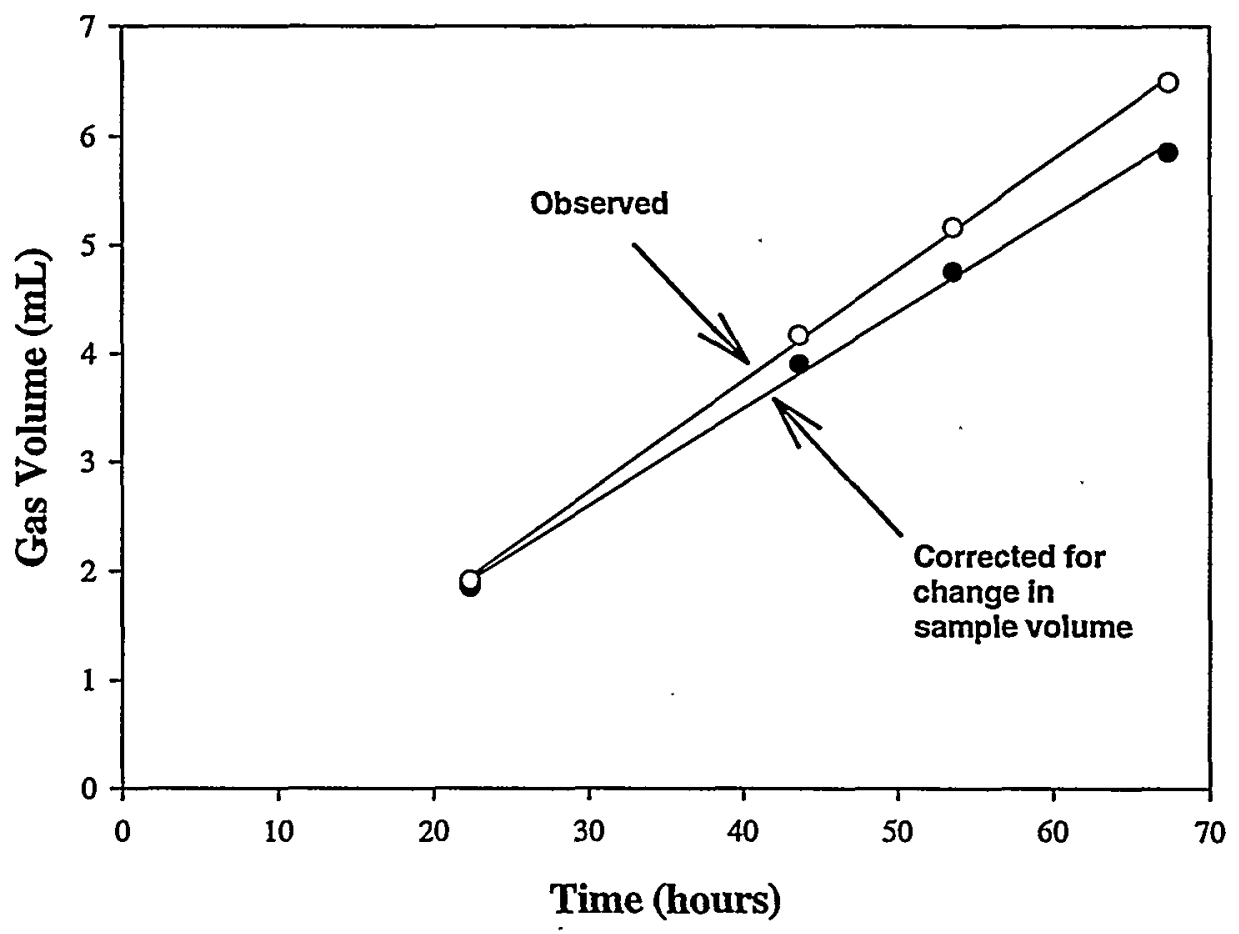

High OH/IONSIVTM IE-911 slurry $G_{\text {tot }}=0.076$ molecules $/ 100 \mathrm{eV}$ (Table II) 
TABLE III. Gas Compositions*

Sample

High nitrate solution

High nitrate/

IONSIV ${ }^{\text {TM }} \mathbb{I E}^{-911}$ slurry
Gas Composition (vol \%)

$\underline{\mathrm{H}_{2}} \quad \underline{\mathrm{O}_{2}} \quad \underline{\mathrm{N}_{2} \mathrm{O}} \quad \underline{\mathrm{CO}} \quad \underline{\mathrm{N}_{2}} \quad \underline{\text { Other }} *$ Sum

$\begin{array}{lllllll}20.8 & 72.7 & <.13 & 0.01 & 7.2 & 0.1 & 100.8\end{array}$

$\begin{array}{lllll}22.1 & 74.3 & <.1 & 2.5 & 0.1\end{array}$

$1.0 \quad 96.9$

$\begin{array}{lllll}23.2 & 69.7 & 0.35 & 2.5 & 1.1\end{array}$

$\begin{array}{lllll}25.4 & 68.0 & 0.32 & 2.4 & 1.5\end{array}$

High $\mathrm{OH} /$

$\begin{array}{llllllll}\text { IONSIVTM IE-911 slurry } & 61.9 & 15.4 & 3.8 & 0.35 & 5.5 & 2.5 & 89.5 \\ & 63.2 & 14.8 & & 0.23 & 6.0 & 3.6 & \end{array}$

*Dose rate for all data was $9.8 \times 10^{5} \mathrm{rad} / \mathrm{h}$.

**Sum of methane and ethane.

TABLE IV. G Values for Individual Gases

Sample

High nitrate solution

High nitrate/IONSIVTM IE-911 slurry

High OH/IONSIV TM IE-911 slurry
G Value (molecule/100 eV)

$\underline{\mathrm{H}_{2}} \quad \underline{\mathrm{O}_{2}} \quad \underline{\mathrm{N}_{2} \mathrm{O}}$

$0.038 \pm .001 \quad 0.128 \pm .004<.0002$

$0.028 \pm .002 \quad 0.078 \pm .003 \quad 0.0026$

$0.058 \pm .002 \quad 0.0124 \pm .0011 \quad 0.0036$

*Based on total dose (i.e., energy adsorbed by solid and liquid phases) and corrected for sampling impurities.

Combining the gas compositions in Table $\mathrm{II}$ with the total gas generation rates in Table II allows the calculation of $G$ values for the production of each gas. Table $I V$ lists $G$ values for hydrogen, oxygen, and nitrous oxide. These calculations assume the nitrogen and a portion of the oxygen (proportional to the nitrogen) result from air contamination during sampling. The methane, ethane, and carbon monoxide impurities identified in the samples come from radiolytic breakdown of the rubber septum used to seal the vials. This correction to the oxygen yield is minor for the high nitrate solution $(<3 \%)$ and the high nitrate IONSIVTM $\mathbb{E}-911$ slurry $(<1 \%)$, but is significant for the high hydroxide slurry $(\sim 10 \%)$. 
Table $V$ lists the $G$ values based on the doses to the liquid phase of each sample. A previous investigation ${ }^{3}$ found no evidence for enhanced hydrogen production in the presence of IONSIV ${ }^{\mathrm{TM}}$ IE-911 when calculated on a dose-to-solution basis. In this study, the $\mathrm{G}$ value observed for hydrogen generation in the high nitrate slurry $(0.052$ molecules $/ 100 \mathrm{eV})$ is close to the expected value $(0.047$ molecules $/ 100 \mathrm{eV})$ based on the nitrate and nitrite concentrations. ${ }^{5}$ However, the high hydroxide slurry generated hydrogen at almost twice the expected rate. The expected rate was 0.063 molecules $/ 100$ $\mathrm{eV}$ compared to the observed 0.122 molecules $/ 100 \mathrm{eV}$.

The oxygen yields agree with the relatively few previous measurements on SRS waste solutions. For the high nitrate slurry, oxygen generated at three times the hydrogen rate. This is somewhat less than the six-fold rate difference observed in a measurement on SRS radioactive waste, ${ }^{6}$ but the discrepancy likely results from differences in solution composition.

Nitrous oxide is a relatively minor constituent of the radiolytically generated gases. Researchers previously reported finding $\mathrm{N}_{2} \mathrm{O}$ when nitrite or a combination of nitrate and organic compounds are irradiated..$^{7-8}$

\section{SUMMARY}

Researchers investigated both the rate of production and composition of gases generated from Co-60 gamma irradiation of IONSIVTM IE-911 slurries in simulated SRS waste. The dose rate in these studies $(\sim 1 \mathrm{Mrad} / \mathrm{h})$ was similar to the dose rate expected in a large ion exchange column loaded with $\mathrm{Cs}-137(0.8 \mathrm{Mrad} / \mathrm{h})$.

Irradiating a small column $(1.5 \mathrm{~cm}$ diam $\mathrm{x} 10 \mathrm{~cm}$ long) produced gas bubbles in less than eight hours. A previous calculation suggests that bubbles could form in a few minutes. ${ }^{1}$ This prediction could be easily verified by the method used in this test by simply making observations at shorter time intervals. Observations at longer time periods indicate the

TABLE V. G Values for Gas Generation Based on Dose to Liquid Phase*

Sample

High nitrate/IONSIV ${ }^{\mathrm{TM}}$ IE-911 slurry

High OH/IONSIV'M IE-911 slurry

\section{G Value (molecule/100 eV)}

$\underline{\mathbf{H}_{2}}$

$\underline{\mathbf{O}_{2}}$

$\underline{\mathrm{N}_{2}} \mathrm{O}$

0.052

0.145

0.0009

0.121

0.026

0.008

\footnotetext{
*Based on dose to liquid phase with the energy apportioned by weight. The high nitrate and high hydroxide slurries contained $47 \mathrm{wt} \%$ and $48 \mathrm{wt} \%$ liquid phase, respectively.
} 
behavior of the gas bubbles depends on their depth in the column. Bubbles near the surface of a static column percolate to the surface by pushing the IONSIV ${ }^{\mathrm{TM}}$ IE-911 particles aside. Bubbles at greater depths produce gas channels between static IONSIVTM IE-911 particles. Some expansion of the bed occurs. Greater pressures in large columns may produce significantly different behavior.

Under high dose rates in the presence of IONSIV ${ }^{\mathrm{TM}}$ IE-911, the composition of gases measured in these tests agrees with previous results in the absence of IONSIVTM $\mathbb{E}-911$. Radiation produces mainly hydrogen and oxygen with small amounts $(<4 \%)$ of nitrous oxide. The ratio of hydrogen to oxygen.varies depending on the waste composition. At low nitrate concentrations, hydrogen production exceeds oxygen by up to $500 \%$. Alternatively, at high nitrate concentrations, oxygen production exceeds hydrogen by up to $300 \%$. The hydrogen production rate in high nitrate IONSIV ${ }^{\mathrm{TM}}$ IE-911 slurries agrees with previous work without IONSIV'M IE-911 present. Previous tests indicated similar agreement in average waste IONSIV ${ }^{\mathrm{TM}}$ IE-911 slurries. ${ }^{3}$ However, the current tests in high hydroxide IONSIV ${ }^{\mathrm{TM}} \mathrm{IE}-911$ slurries generated twice as much hydrogen as expected. This unexpected result deserves additional investigation. The test with high hydroxide slurry was unusual in three aspects that may contribute to the calculated high rate of hydrogen production: the correction to the oxygen concentration, the impurity organics from the septum, and amount of unidentified gas were all larger than in the high nitrate tests. With the exception of the high hydroxide waste, gas generation can be calculated based on dose to the liquid phase using $\mathrm{G}$ values obtained from solutions without IONSIVTM IE-911 present.

\section{ACKNOWLEDGMENTS}

The authors thanks W. C. Sexton of the SRTC Glass Shop for the design and fabrication of the apparatus used in the experiments. J. A. Young of the Analytical Development Section provided nitrous oxide analyses. B. H. Croy of Waste Processing Technology Section prepared solutions, monitored gas generation, and operated the WPTS gas chromatograph.

\section{REFERENCES}

1. High Level Waste Salt Disposition Systems Engineering Team, "Position Paper on Performance of Small CST Column Gas Generation Test in Radiation Field," HLW-SDT99-0257, Rev.0, August 30, 1999.

2. P. L. Rutland et al., "Bases, Assumptions, and Results of the Flowsheet Calculations for the Initial Eighteen Salt Disposition Alternatives", WSRC-RP-98-00166, 25 June 1998. 
3. N. E. Bibler, C. L. Crawford, and C. R. Biddle, "Results of Scoping Studies for Determining Radiolytic Hydrogen Production from Moist CST and CST Slurries," WSRC-RP-98-01143, October 2, 1998.

4. D. D. Walker, "Cesium Removal from Savannah River Site Radioactive Waste Using Crystalline Silicotitanate," WSRC-TR-99-00308, Rev.0, September 15, 1999.

5. C. L. Crawford and D. D. Walker, "Hydrogen Generation by Radiolysis of Tetraphenylborate Solutions and Slurries (U)," WSRC-TR-96-0109, Rev.0, June 19, 1996.

6. D. T. Hobbs, P. W. Norris, S. A. Pucko, N. E. Bibler, D. D. Walker, and P. D. d'Entremont, "Hydrogen Generation Rates in Savannah River Site High-Level Nuclear Waste," Proceedings of Waste Management '92, Vol. 1, University of Arizona, March 15, 1992, pp 1063-1065 (1992).

7. D. D. Walker, C. L. Crawford, and N. E. Bibler, "Radiolytic Bubble Formation and Level Changes in Simulated High-Level Waste Salts and Sludges - Application to HLW Storage Tanks," Proceedings of Waste Management '94, Vol.1, University of Arizona, February 27 to March 3, 1994, pp 393-396.

8. D. D. Walker, D. T. Hobbs, J. B. Tiffany, N. E. Bibler, and D. Meisel, "Nitrous Oxide Production from Radiolysis of Simulated High-Level Nuclear Waste Solutions," Proceedings of Waste Management '92, Vol.1, University of Arizona, March 1-5, 1992, pp.855-858.

9. H. M. Rizvi, "Cobalt Source Calibration," WSRC-TR-99-00303, Rev. 0, September 1, 1999. 


\section{APPENDIX A \\ Experimental}

\section{Preparation of Salt Solutions}

Researchers prepared simulated SRS waste solutions with the compositions shown in Table I using reagent grade chemicals and volumetric glassware. Personnel measured the densities of the salt solutions by weighing the solutions in the volumetric flasks used in the preparation.

\section{Crystalline Silicotitanate}

The experiments used crystalline silicotitanate in the engineered form, IONSIV'M IE-911, Lot \#999098810005, manufactured by UOP LLC., Molecular Sieves Division, Des Plaines, $\mathbb{I}$. The as-received particles contained $5.9 \pm 0.7 \mathrm{wt} \%$ water determined by drying 0.2 gram samples to constant weight at $105^{\circ} \mathrm{C}$. All experiments used pretreated portions of IONSIV ${ }^{\mathrm{TM}} \mathbb{E}-911$. Pretreatment consisted of equilibration with moist air for 3 days, removal of fines with flowing water, and $\mathrm{pH}$ adjustment with sodium hydroxide solution. The sodium hydroxide solution was displaced with simulated waste solution by repeated batch dilutions.

\section{Radiation Sources}

Researchers used a Shepherd Model 109 Co-60 Gamma Source (Building 773-A, Room C-067) for high dose rate experiments and a Co-60 gamma ray source shielded by water (Building 774-A) for low dose rate experiments. The Building 774-A source is located under 28 feet of shielding water. Waterproof secondary containers hold the samples in an

\section{TABLE A-1. Co-60 Gamma Ray Sources}

$\begin{array}{lll}\text { Source name: } & \begin{array}{l}\text { Shepherd } \\ \text { Model 109 }\end{array} & \text { Source \#2 } \\ \text { Location: } & 773-\mathrm{A}, \mathrm{C}-067 & \begin{array}{l}774-\mathrm{A} \\ \text { Features: }\end{array} \\ & \text { Air cooled } & \begin{array}{l}\text { Secondary container } \\ \text { for samples cooled } \\ \text { by shielding water }\end{array}\end{array}$

$\begin{array}{lcc}\text { Temperature }\left({ }^{\circ} \mathrm{C}\right) & 35 \pm 3 & 28 \pm 3 \\ \text { Dose rate }(\mathrm{rad} / \mathrm{h})(7 / 1 / 99) * & 9.8 \times 10^{5} & 1.04 \times 10^{5}\end{array}$

* Experiments were conducted over a 4 month period between April and July 1999. 
air atmosphere during irradiation. Although not cooled by air circulation as in the Shepherd source, sample temperatures are moderated due to the large volume of shielding water. Table A-1 lists significant conditions for each source. Researchers measured the dose rates for the experimental geometry using Fricke dosimeter solutions. ${ }^{5}$ Tests conducted over four months required small dose rate adjustments for decay of the Co- 60 .

\section{Gas Bubble Formation Test}

The SRTC Glass Shop fabricated fused-quartz cylinders $(1.5 \mathrm{~cm} \mathrm{ID} \mathrm{x} 13 \mathrm{~cm}$ long) for this experiment (Figure 1). Quartz does not darken upon exposure to radiation as does borosilicate glass. Slurries of IONSIV ${ }^{\mathrm{TM}} \mathrm{IE}-911$ in high nitrate salt solution or $0.1 \mathrm{M}$ $\mathrm{NaOH}$ solution filled the quartz cylinders to a depth of $6.0 \mathrm{~cm}(10.6 \mathrm{~mL})$. The 6-cm deep packed bed was covered with $2.0 \mathrm{~cm}$ of clear liquid. The Shepherd gamma ray source irradiated the slurries for seven days at a dose rate of $1.01 \times 10^{6} \mathrm{rad} / \mathrm{h}$. Researchers visually examined the quartz cylinders for gas bubbles after 8 hours of irradiation and daily thereafter. Room temperature air injected into the irradiation chamber maintained the sample temperature at $36 \pm 1^{\circ} \mathrm{C}$.

\section{Gas Generation and Composition Tests}

The SRTC Glass Shop fabricated the borosilicate glass vessel illustrated in Figure A-1. The vessel consists of two chambers separated by a coarse porosity glass frit. One chamber holds the sample. A silicone septum covered with copper foil seals the sample chamber and provides access for syringe removal of gas samples for analysis. The other chamber is a graduated cylinder open to the atmosphere. Gases generated by irradiation of the sample are collected in the sealed chamber. Liquid displaced by the gas passes through the glass frit. The volume displaced from the sealed chamber is measured in the graduated cylinder.

Researchers placed a cork in the graduated cylinder and then filled the sample chamber with either salt solution or slurries of IONSIV ${ }^{T M} \mathbb{E}-911$. Weighing the apparatus empty and filled determined the amount of sample present. The cork was removed and about $1.5 \mathrm{~mL}$ of salt solution was placed in the graduated cylinder to seal the glass frit. The apparatus was placed in a Co-60 gamma source and irradiated for 3 days to 3 weeks. The volume of liquid in the graduated cylinder was periodically recorded. At the end of the irradiation, the vessel was allowed to return to room temperature. A portion of the trapped gas was removed and analyzed. Due to hardening of the septum during irradiation, a second septum was placed over the irradiated septum to maintain integrity when the gas sample was taken by syringe. During syringe sampling, researchers took care to avoid air contamination. However, 2-7 vol. \% nitrogen was found. The variability of the nitrogen yield suggests its origin is air contamination rather than radiolytic generation. The oxygen yields were adjusted downward assuming the nitrogen present represented air contamination. In all cases this correction was minor and represented less than a $5 \%$ change in the oxygen yield. The copper foil did not completely prevent contamination of the samples with variable minor amounts $(0.1$ to 
WSRC-TR-99-00285, Rev. 0

Page 17 of 19

$4 \%$ ) of $\mathrm{CH}_{4}, \mathrm{C}_{2} \mathrm{H}_{6}$, and $\mathrm{CO}$ from the radiolytic degradation of the silicone septa. Control tests in the absence of salt solution or IONSIV ${ }^{\mathrm{TM}} \mathbb{E}$-911 demonstrated these gases originated from the septa. No useful data was obtained from tests using the low dose rate source. The irradiation vessels leaked air during the test so the data was discarded.

Researchers calculated the gas generation rates as $\mathrm{G}$ values (molecules $/ 100 \mathrm{eV}$ ) assuming ideal gas behavior and $1 \mathrm{~atm}$ pressure in the apparatus. No correction was made for water vapor in the samples. The vapor pressure of water at $25^{\circ} \mathrm{C}$ is $23 \mathrm{~mm} \mathrm{Hg}$ (i.e., approximately $3 \mathrm{vol} \%$ ) and will be less over salt solutions. The gas generation rate (in $\mathrm{mL} / \mathrm{h} / \mathrm{g}$ ) was corrected for loss of solution displaced from the sealed section of the apparatus. No correction was made for the recombination of gases in the radiation field.

The calculation of the dose to the solution requires knowledge of the masses of IONSIV ${ }^{\mathrm{TM}}$ IE-911 and simulated waste solution in the packed bed. Researchers assume the dose to the liquid phase is the fraction of the total dose equal to the mass fraction of the liquid phase. The previous calculation of gas generation rates ${ }^{1}$ assumed the bed contained 50 vol \% particles, the IONSIV ${ }^{\mathrm{TM}}$ IE-911 particles were $24 \mathrm{vol} \%$ void space, the packed dry particle density was $1.0 \mathrm{~g} / \mathrm{mL}$, the solution density is $1.26 \mathrm{~g} / \mathrm{mL}$, and the IONSIV ${ }^{\mathrm{TM}} \mathbb{E}-911$ solid phase density was $2.6 \mathrm{~g} / \mathrm{mL}$. These assumptions yield a calculated dose to the liquid phase equal to $44 \%$ of the total dose (or, alternatively, the IONSIV TM IE-911 absorbs 56\% of the radiation). In these experiments, a small amount of excess liquid phase was present above the packed bed yielding calculated doses to the liquid phases of 46 (high hydroxide waste simulant) and $48 \%$ (high nitrate waste simulant) of the total dose.

\section{Analytical Methods}

Analytical Development Section (ADS) personnel performed routine analyses to verify the composition of the salt solutions. ADS personnel analyzed gas compositions with a Hewlett-Packard Model 5890 gas chromatograph with a Hewlett-Packard Model 5971 mass spectrometer. A $30 \mathrm{~m} \times 0.53 \mathrm{~mm}$ Carboxen-1006 porous layer open tubular capillary column separated the gas components.

Waste Processing Technology Section personnel analyzed gas compositions with a Varian Model 3400 gas chromatograph containing thermal conductivity and flame ionization detectors. Chromosorb-106 and molecular sieve 13X columns separated the gas components. Researchers calibrated the detector response for $\mathrm{H}_{2}, \mathrm{O}_{2}, \mathrm{~N}_{2}, \mathrm{CO}$, and $\mathrm{CO}_{2}$ with NIST traceable gas standards (Scott Specialty Gases, $\pm 5 \%$ accuracy) . 
Figure A-1. Apparatus for Gas Generation Rate Measurements

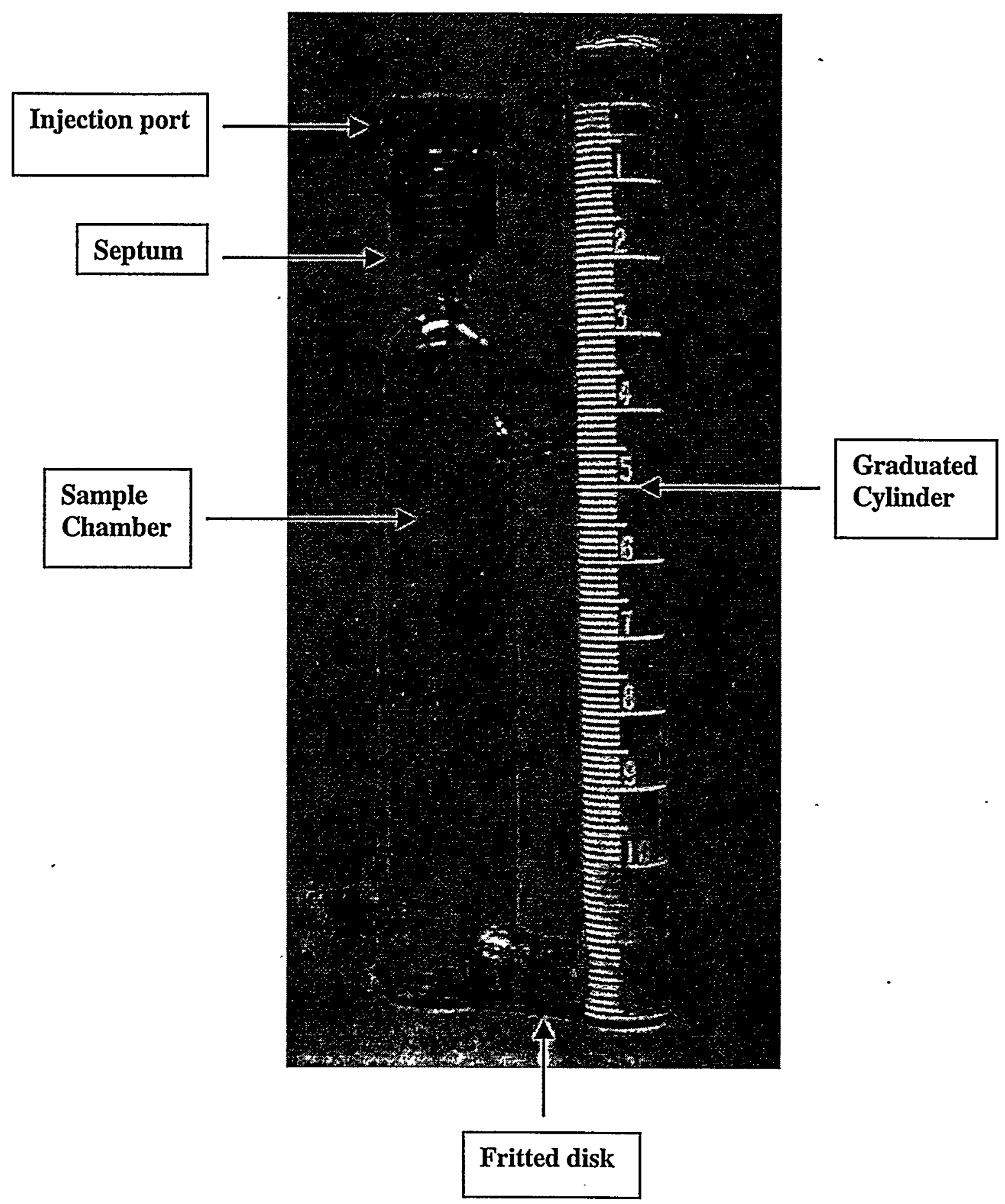




\section{DISTRIBUTION:}

G. E. Abell, 704-3N

B. N. Attaway, 773-A

J. L. Barnes, 704-3N

M. J. Barnes, 773-A

S. B. Beck, 704-3N

J. T. Carter, 704-3N

G. L. Cauthen, 241-119H

W. C. Clark, 704-56H

N. R. Davis, 703-H

R. A. Dimenna, 773-42A

L. O. Dworjanyn, 735-11A

H. H. Elder, 704-S

S. D. Fink, 773-A

F. F. Fondeur, 773-A

J. R. Fowler, 704-3N

J. C. Griffin, 773-A

T. Hang, 773-42A

D. C. Hannah, 703-46A

D. T. Hobbs, 773-A

E. W. Holtzscheiter, 773-A

M. Howell, 704-19@

P. I. Hudson, 704-3N

P. R. Jackson, 703-46A

R. A. Jacobs, 704-3N

M. D. Johnson, 703-H

R. T. Jones, 704-3N

E. J. Kosiancic, 704-3N

L. F. Landon, 704-T

B. L. Lewis, 703-H

T. J. Lex, 703-H

P. E. Lowe, 773-41A

D. J. McCabe, 773-42A

J. W. McCullough, 703-H

M. S. Miller, 704-56H
T. M. Monahon, 703-H

J. P. Morin, 703-H

E. T. Murphy, 704-3N

C. A. Nash, 773-42A

L. M. Nelson, 773-43A

L. M. Papouchado, 773-A

P. K. Paul, 773-42A

R. A. Peterson, 773-A

S. F. Piccolo, 704-3N

J. A. Pike, 704-3N

M. R. Poirier, 676-T

M. J. Polochko, 773-A

J. Reynolds, $704-19 \Subset \mathrm{N}$

K. J. Rueter, 704-3N

P. L. Rutland, $704-19 \mathrm{~N}$

M. G. Schwenker, 703-46A

R. H. Spires, 703-H

W. E. Stevens, 773-A

P. C. Suggs, $704-19 \Subset \mathrm{N}$

W. L. Tamosaitis, 773-A

G. A. Taylor, $704-19 \Subset \mathrm{N}$

W. B. VanPelt, 773-43A

D. D. Walker, 773-A

W. R. Wilmarth, 773-42A

G. T. Wright, 773-A

J. E. Young, 773-A

TIM, 703-43A

WPTS Files, 773-A, c/o Cathy Canada,773A

ITP Files c/o Cathy Smalls, 241-147H 